Vol 3 No 2 Mei 2020

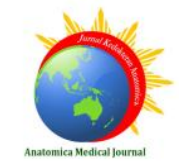

E-ISSN: 2614-5219

ARTIKEL PENELITIAN

\title{
Faktor-Faktor yang Mempengaruhi Visus pada Mahasiswa Fakultas Kedokteran Universitas HKBP Nommensen
}

\author{
Ade Pryta R. Simaremare \\ Fakultas Kedokteran Universitas HKBP Nommensen \\ e-mail: adesimaremare@uhn.ac.id
}

\begin{abstract}
Abstrak: World Health Organization melalui Vision 2020 merekomendasikan ketersediaan data mengenai keadaan kebutaan dan gangguan penglihatan melalui penelitian yang berkesinambungan sehingga kelainan refraksi dapat dikoreksi lebih dini dan dapat menurunkan jumlah kebutaan pada tahun 2020. Penelitian ini bertujuan mengetahui faktor yang mempengaruhi tajam penglihatan pada mahasiswa Fakultas Kedokteran Universitas HKBP Nommensen.Metode: Penelitian ini menggunakan desain observasional analitik dengan metode cross sectional. Sebanyak 112 responden dipilih dengan teknik simple random sampling. Data mengenai faktor-faktor yang mempengaruhi visus diperoleh melalui kuisioner. Data hasil pengukuran visus diperoleh dengan Snellen chart. Hasil: Mayoritas mahasiswa Fakultas Kedokteran Universitas HKBP Nommensen mengalami penurunan visus yaitu sebesar 75,9\%. Faktor-faktor yang mempengaruhi visus oculi dextra dan sinistra secara statistik pada penelitian ini adalah kebiasaan jarak membaca (nilai $\mathrm{p}=0,015$ dan $\mathrm{p}=0,028$ ) dan jenis sayuran kesukaan (nilai $\mathrm{p}=0,044$ dan $\mathrm{p}=0,006$ ). Faktor-faktor seperti kebiasaan posisi membaca, rerata screentime, dan kebiasaaan makan sayur secara statistik tidak mempengaruhi visus pada penelitian ini $(\mathrm{p}>0,05)$. Kesimpulan: Kebiasaan jarak membaca yang kurang baik dan jenis sayuran kesukaan mempengaruhi penurunan visus pada mahasiswa kedokteran dalam penelitian ini.

Kata kunci: tajam penglihatan, faktor pengaruh, mahasiswa kedokteran, kebiasaan membaca
\end{abstract}

\section{Factors Affecting the Visual Acquity of Students of Universitas HKBP Nommensen Medical Faculty}

Abstract: World Health Organization through Vision 2020 recommended the availability of the state of blindness and visual impairment data through continuous research so that refractive disorders can be corrected early and reduce the number of 
blindness in 2020. This study aimed to find out the factors affecting the vision in students of the Medical Faculty of Universitas HKBP Nommensen. Method: This was an observational analytic study design with cross sectional method. The 112 respondents were selected by simple random sampling technique. The factors that influence the vision obtained through questionnaires and the visual measurement used Snellen chart. Results: The majority of respondents experienced vision decrease (75.9\%). This study showed factors affecting the vision of dextra and sinistra oculis were the habit of reading distance ( $p$ value $=0.015$ and $p=0.028$ ) and the type of favorite vegetables ( $p=0.044$ and $p=0.006)$. Factors such as habits of reading position, mean screentime, and eating vegetables statistically did not affect vision ( $p$ >0.05). Conclusion: Poor reading distance habits and the type of favourite vegetables decreased visual acquity of medical students in this study.

Keywords: visual acuity, affecting factors, medical students, reading habits

\section{PENDAHULUAN}

Mata adalah salah satu indera yang penting bagi manusia. Namun gangguan terhadap penglihatan banyak terjadi, mulai dari gangguan ringan berupa kelainan tajam penglihatan hingga gangguan yang berat yang dapat mengakibatkan kebutaan. ${ }^{1}$ Kelainan tajam penglihatan merupakan masalah kesehatan yang banyak dijumpai terkhusus pada anak usia sekolah. ${ }^{2}$ Prevalensi terbesar yang didapatkan pada anak usia sekolah disebabkan karena kelainan refraksi. Kelainan tajam penglihatan yang disebabkan oleh kelainan refraksi menghasilkan bayangan yang kabur sehingga mengganggu proses melihat yang normal. Gangguan ketajaman penglihatan yang tidak terkoreksi masih sangat banyak terjadi pada anakanak karena kurangnya kesadaran orang tua untuk rutin melakukan pemeriksaan secara rutin. ${ }^{3,4}$

Di seluruh dunia, terdapat jumlah yang signifikan yang menderita karena tajam penglihatan yang buruk. Diperkirakan terdapat 2,5 miliar orang di dunia dengan permasalahan penglihatan yang tidak mendapatkan koreksi. ${ }^{5}$ Data dari VISION 2020, suatu program kerjasama antara International Agency for the Prevention of Blindness (IAPB) dan World Health Organization (WHO) memperkirakan 153 juta penduduk dunia mengalami gangguan visus akibat kelainan refraksi yang tidak 
dikoreksi. Dari 153 juta orang tersebut, sedikitnya 13 juta diantaranya adalah anak usia 5-15 tahun. ${ }^{6}$

Di Indonesia prevalensi kelainan refraksi menempati urutan pertama pada penyakit mata. Menurut hasil Riset Kesehatan Dasar (Riskesdas) Tahun 2013 proporsi pengguna kaca mata atau lensa kontak pada penduduk umur di atas 6 tahun di Indonesia adalah sebesar $4,6 \%$, dengan proporsi penurunan tajam penglihatan sebesar 0,9\%. Proporsi pengguna kaca mata atau lensa kontak pada penduduk dengan umur di atas 6 tahun di provinsi Sumatera Utara adalah sebesar 4,0\%, proporsi penurunan tajam penglihatan sebesar $0,9 \%$ dan proporsi kebutaan sebesar $0,3 \%$. Jumlah gangguan penglihatan yang tidak terkoreksi pada kelompok usia anak-anak (berusia di bawah 18 tahun) pada tahun $2010 \mathrm{di}$ dunia diperkirakan 810 juta dengan presentase sebesar 30\%. Presentase tersebut tersebar secara bervariasi di seluruh dunia, dengan prevalensi yang signifikan terdapat pada beberapa negara berkembang. ${ }^{1,7}$
Untuk menangani permasalahan kebutaan dan gangguan penglihatan, World Health Organization (WHO) membuat program Vision 2020, the right to sight, yang direkomendasikan untuk diadaptasi oleh negara-negara anggotanya. Vision 2020 adalah suatu inisiatif global untuk penanganan kebutaan dan gangguan penglihatan di seluruh dunia. Tujuan program ini untuk menanggulangi masalah kebutaan yang dapat dicegah atau direhabilitasi. Kegiatan yang direkomendasikan oleh $W H O$ melalui Vision 2020 adalah ketersediaan data mengenai keadaan kebutaan dan gangguan penglihatan melalui penelitian yang diselenggarakan berkesinambungan sampai di tingkat distrik. Sehingga kelainan refraksi dapat dikoreksi lebih dini dan dapat menurunkan jumlah kebutaan pada tahun 2020. . $^{1,8}$

Beberapa penelitian menemukan berbagai faktor yang mungkin dapat mempengaruhi tajam penglihatan seseorang. Di antara faktor-faktor tersebut ialah kebiasaan membaca ${ }^{9}$, 
paparan cahaya computer/ gadget ${ }^{10}$ dan penggunaan game online ${ }^{11}$. Oleh karena pentingnya masalah kesehatan mata ini, terkhusus bagi seseorang dalam usia belajar, maka peneliti akan melakukan penelitian untuk mengetahui faktor-faktor yang dapat mempengaruhi tajam penglihatan pada mahasiswa Fakultas Kedokteran Universitas HKBP Nommensen Medan.

\section{METODE}

Penelitian ini menggunakan disain observasional analitik dengan metode cross sectional dengan sampel seluruh mahasiswa Fakultas Kedokteran Universitas HKBP Nommensen yang diambil dengan teknik simple random sampling. Data mengenai faktor-faktor yang dapat mempengaruhi visus pada mahasiswa fakultas kedokteran di Kota Medan (kebiasaan jarak membaca, posisi membaca, rerata penggunaan smartphone, kebiasaan makan sayur) diperoleh melalui pengisian kuesioner. Sedangkan pengukuran visus responden diperoleh menggunakan alat bantu Snellen chart.

Data karakteristik responden ditampilkan dalam tabel distribusi frekuensi. Analisis bivariat dilakukan untuk melihat hubungan faktor yang mempengaruhi visus dengan hasil pengukuran visus responden. Uji hipotesis yang digunakan adalah uji Chi-square karena variabel bebas pada penelitian ini adalah kategorik. Selanjutnya bila nilai $p<0,25$ maka akan masuk ke analisis regresi logistik untuk memprediksi ada atau tidak adanya variabel yang paling kuat hubungannya. Analisis ini menggunakan regresi logistik biner dengan metode backward LR. Dimana analisis yang dilakukan secara bertahap dengan mengeliminasi variabel yang tidak sesuai ketentuan secara otomatis.

\section{HASIL}

\section{Gambaran Visus Mahasiswa}

Responden pada penelitian ini adalah 112 orang mahasiswa yang sedang aktif dalam perkuliahan di kampus yaitu angkatan 2019, 2018, dan 
2017. Frekuensi jumlah responden berdasarkan angkatan dan jenis kelamin telah dirangkum dalam tabel 1. Dari tabel terlihat bahwa responden terbanyak berasal dari angkatan 2019, hal ini dikarenakan di angkatan tersebut jumlah mahasiswa terbanyak diterima dari hasil seleksi mahasiswa yaitu 105 orang, sedangkan mahasiswa angkatan 2018 berjumlah 75 orang, dan angkatan 2017 berjumlah 41 orang. Responden mayoritas berjenis kelamin perempuan, hal ini dikarenakan pada setiap angkatan jumlah mahasiswa perempuan lebih banyak dibandingkan laki-laki.

Gambaran visus responden dapat diamati pada tabel 2. Visus yang normal adalah tajam penglihatan dengan nilai $6 / 6$ atau nilai $\geq 0,8$ bila dikonversikan ke nilai desimal untuk masing-masing mata setelah dilakukan pemeriksaan dengan Snellen chart. Penurunan tajam penglihatan ringan didefinisikan dengan konversi hasil Snellen chart dengan desimal 0,790,3 ; penurunan sedang dengan nilai desimal 0,29-0,125; penurunan berat dengan nilai desimal $0,124-0,05$; penurunan profound dengan nilai desimal 0,05 - 0,02; near blindness dengan nilai desimal kurang dari 0,02 hingga tidak ada persepsi cahaya (no light perception). 
Vol 3 No 2 Mei 2020

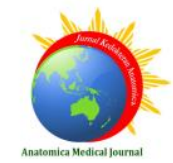

E-ISSN: 2614-5219

Tabel 1. Distribusi Frekuensi Visus Responden Berdasarkan Angkatan dan Jenis Kelamin

\begin{tabular}{|c|c|c|c|c|c|c|c|}
\hline \multirow{2}{*}{\multicolumn{2}{|c|}{ Kategori }} & \multirow{2}{*}{$\begin{array}{c}\text { Frekuensi } \\
\text { (n) }\end{array}$} & \multirow[b]{2}{*}{$\%$} & \multicolumn{2}{|c|}{ VOD } & \multicolumn{2}{|c|}{ VOS } \\
\hline & & & & Norma & & Norma & Menuru \\
\hline \multirow{3}{*}{$\begin{array}{c}\text { Angkat } \\
\text { an }\end{array}$} & 2017 & 22 & 19,6 & 9 & 13 & 8 & 14 \\
\hline & 2018 & 39 & 34,8 & 4 & 35 & 7 & 32 \\
\hline & 2019 & 51 & 45,5 & 14 & 37 & 11 & 40 \\
\hline \multirow{2}{*}{$\begin{array}{c}\text { Jenis } \\
\text { Kelami } \\
\text { n }\end{array}$} & $\begin{array}{l}\text { Laki- } \\
\text { laki }\end{array}$ & 32 & 28,6 & 9 & 23 & 9 & 23 \\
\hline & $\begin{array}{c}\text { Perempu } \\
\text { an }\end{array}$ & 80 & 71,4 & 18 & 62 & 17 & 63 \\
\hline
\end{tabular}


Tabel 2. Gambaran Visus

Responden

\begin{tabular}{ccccc}
\hline \multirow{2}{*}{ Kategori } & $\begin{array}{c}\text { Visus Oculi } \\
\text { Dextra }\end{array}$ & \multicolumn{2}{c}{$\begin{array}{c}\text { Visus Oculi } \\
\text { Sinistra }\end{array}$} \\
\cline { 2 - 5 } & & & \\
n & $\%$ & n & $\%$
\end{tabular}

\begin{tabular}{|c|c|c|c|c|c|}
\hline Normal & 27 & 24.1 & 26 & 23.2 & membaca dengan nilai $\mathrm{p}=0,015$ dan \\
\hline $\begin{array}{l}\text { Penuruna } \\
\text { n ringan }\end{array}$ & 45 & 40.2 & 51 & 45.5 & $\begin{array}{l}\text { 0,028; dan ada tidaknya sayuran } \\
\text { kesukaan dengan nilai } \mathrm{p}=0,044 \text { dan } \\
0,006 \text {. Sedangkan kebiasaan posisi }\end{array}$ \\
\hline $\begin{array}{l}\text { Penuruna } \\
\text { n sedang }\end{array}$ & 21 & 18.8 & 21 & 18.8 & $\begin{array}{l}\text { membaca, rerata screentime, dan } \\
\text { kebiasaan makan sayur tidak }\end{array}$ \\
\hline $\begin{array}{l}\text { Penuruna } \\
\mathrm{n} \text { berat }\end{array}$ & 10 & 8.9 & 8 & 7.1 & $\begin{array}{l}\text { mempengaruhi tajam penglihatan pada } \\
\text { responden penelitian ini }(\mathrm{p}>0,05) \text {. } \\
\text { Berdasarkan hasil uji bivariat, }\end{array}$ \\
\hline Penuruna & & & & & maka variabel yang dapat diuji ke \\
\hline $\begin{array}{l}\mathrm{n} \\
\text { profound }\end{array}$ & 7 & 6.3 & 5 & 4.5 & $\begin{array}{l}\text { dalam regresi logistik biner adalah } \\
\text { variabel kebiasaan jarak membaca, dan }\end{array}$ \\
\hline $\begin{array}{l}\text { Near } \\
\text { blindness }\end{array}$ & 2 & 1.8 & 1 & 0.9 & $\begin{array}{l}\text { ada tidaknya jenis sayuran kesukaan } \\
\text { responden }(\mathrm{p}<0,25) \text {. Hasil analisis } \\
\text { regresi logistik telah dirangkum pada }\end{array}$ \\
\hline Total & $\begin{array}{c}11 \\
2\end{array}$ & $\begin{array}{c}100 . \\
0\end{array}$ & 112 & 100.0 & tabel 4. \\
\hline
\end{tabular}

masing-masing pada oculi dextra dan sinistra. Dari tabel tersebut terlihat bahwa secara statistik faktor-faktor yang mempengaruhi visus masingmasing pada oculi dextra dan sinistra responden ialah kebiasaan jarak membaca dengan nilai $\mathrm{p}=0,015$ dan

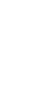

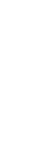


E-ISSN: 2614-5219

Tabel 3. Faktor-faktor yang Mempengaruhi Visus

\begin{tabular}{|c|c|c|c|c|c|c|c|}
\hline \multirow{2}{*}{\multicolumn{2}{|c|}{ Karakteristik }} & \multicolumn{2}{|c|}{ Visus Oculi Dextra } & \multirow{2}{*}{$\begin{array}{c}\mathbf{P} \\
\text { Value }\end{array}$} & \multicolumn{2}{|c|}{ Visus Oculi Sinistra } & \multirow{2}{*}{$\begin{array}{c}\mathrm{P} \\
\text { Value }\end{array}$} \\
\hline & & Normal & Penurunan & & Normal & Penurunan & \\
\hline \multirow{2}{*}{$\begin{array}{l}\text { Kebiasaan } \\
\text { Jarak Baca }\end{array}$} & $\begin{array}{l}<30 \\
\mathrm{~cm}\end{array}$ & 10 & 54 & \multirow{2}{*}{0,015} & 10 & 54 & \multirow{2}{*}{0,028} \\
\hline & $\begin{array}{l}\geq 30 \\
\mathrm{~cm}\end{array}$ & 17 & 31 & & 16 & 32 & \\
\hline \multirow[b]{2}{*}{$\begin{array}{l}\text { Kebiasaan } \\
\text { Posisi }\end{array}$} & $\begin{array}{l}\text { Posisi } \\
\text { tegak }\end{array}$ & 8 & 33 & \multirow{3}{*}{0,388} & 9 & 32 & \multirow{3}{*}{0,810} \\
\hline & $\begin{array}{l}\text { Posisi } \\
\text { duduk }\end{array}$ & & & & & & \\
\hline Baca & $\begin{array}{l}\text { tidak } \\
\text { tegak/ } \\
\text { tiduran }\end{array}$ & 19 & 52 & & 17 & 54 & \\
\hline \multirow{2}{*}{$\begin{array}{l}\text { Rerata } \\
\text { Screentime }\end{array}$} & $\begin{array}{l}\leq 2 \\
\text { jam }\end{array}$ & 4 & 15 & \multirow{2}{*}{0,733} & \multicolumn{2}{|r|}{13} & \multirow{2}{*}{0,343} \\
\hline & $\begin{array}{l}>2 \\
\text { jam }\end{array}$ & 23 & 70 & & 20 & 73 & \\
\hline \multirow{3}{*}{$\begin{array}{l}\text { Kebiasaan } \\
\text { Makan } \\
\text { Sayur }\end{array}$} & $\begin{array}{c}\text { Kurang } \\
(<2 \\
\text { porsi/ } \\
\text { hari) }\end{array}$ & 18 & 66 & \multirow{2}{*}{0,251} & 18 & 66 & \multirow{2}{*}{0,438} \\
\hline & $\begin{array}{c}\text { Baik } \\
(\geq 2 \\
\text { porsi/ } \\
\text { hari) }\end{array}$ & 9 & 19 & & 8 & 20 & \\
\hline & Ada & 19 & 74 & 0,044 & 17 & 76 & \\
\hline
\end{tabular}




\begin{tabular}{lccccccc}
\cline { 2 - 3 } Jenis & Tidak & & & & & & \\
Sayuran & ada & 8 & 11 & 9 & 10 & 0,006 \\
Kesukaan & & & & & & \\
\hline
\end{tabular}

Tabel 4. Analisis Regresi Logistik Variabel yang Mempengaruhi Visus

\begin{tabular}{|c|c|c|c|c|c|}
\hline & \multirow{2}{*}{ Variabel } & \multicolumn{2}{|c|}{$\begin{array}{c}\text { Visus Oculi } \\
\text { Dextra }\end{array}$} & \multicolumn{2}{|c|}{ Visus Oculi Sinistra } \\
\hline & & Nilai P & $\mathbf{O R}$ & Nilai $\mathbf{P}$ & $\mathbf{O R}$ \\
\hline \multirow[b]{2}{*}{ Step 1} & Kebiasaan jarak baca & 0,020 & 0,337 & 0,034 & 0,364 \\
\hline & $\begin{array}{l}\text { Jenis sayuran } \\
\text { kesukaan }\end{array}$ & 0,057 & 0,352 & 0,010 & 0,244 \\
\hline
\end{tabular}

\section{DISKUSI}

Dari tabel 2 diketahui bahwa responden yang memiliki visus normal yaitu masing-masing sebanyak 27 orang $(24,1 \%)$ dan 26 orang $(23,2 \%)$ untuk oculi dextra dan sinistra, mayoritas responden mengalami penurunan visus yaitu sebanyak 85 orang $(75,9 \%)$ untuk oculi dextra dan 86 orang $(76,8 \%)$ untuk oculi sinistra. Penurunan visus ini paling banyak pada kategori rendah dengan visus 6/8 sampai dengan 6/16. Pada responden penelitian ini dapat ditemukan kategori near blindness karena memiliki visus 1/60 hingga 1/300 dengan pemeriksaan menggunakan Snellen chart.

Penelitian yang dilakukan oleh Angriyanto terhadap mahasiswa kedokteran di Universitas Hang Tuah dan oleh Adile terhadap anak SMA di Manado yang menunjukkan bahwa mayoritas respondennya mengalami kelainan refraksi (myopia) yaitu masing-masing sebesar $61,4 \%$ dan $72 \%$. Pada penelitian ini, yang menjadi penyebab penurunan visus tersebut adalah kebiasaan membaca dari yang 
cenderung kurang baik, yaitu kebiasaan membaca lama dan pada jarak yang dekat. Kebiasaan ini yang akhirnya dapat menyebabkan lemahnya otot siliaris mata sehingga mengakibatkan gangguan otot untuk melihat jauh. 12,13

Faktor pertama yang berpengaruh terhadap visus pada penelitian ini adalah kebiasaan jarak membaca responden. Responden yang memiliki kebiasaan membaca dengan jarak kurang dari $30 \mathrm{~cm}$ ada sebanyak 64 orang $(57,1 \%)$, sebanyak 54 orang $(84,3 \%)$ dari responden ini mengalami penurunan visus oculi dextra dan oculi sinistra. Sedangkan responden yang memiliki kebiasaan membaca dengan jarak baca lebih dari atau sama dengan $30 \mathrm{~cm}$ ada sebanyak 48 orang $(42,9 \%)$, sebanyak 31 orang $(64,6 \%)$ dari responden ini mengalami penurunan visus dextra, dan 32 orang $(66,7 \%)$ mengalami penurunan visus oculi sinistra. Penelitian yang dilakukan oleh Rozi menunjukkan bahwa responden yang memiliki kebiasaan membaca yang buruk yaitu dengan jarak baca kurang dari $30 \mathrm{~cm}$ ada sebanyak $60 \%$ dari responden, dan jarak membaca ini berhubungan dengan penurunan tajam penglihatan yang terjadi pada $57,1 \%$ responden pada penelitian tersebut. ${ }^{9}$ Hasil yang sama juga ditunjukkan oleh penelitian oleh Sofiani ${ }^{14}$ dan Karim ${ }^{15}$ yaitu adanya hubungan antara jarak membaca dengan kejadian miopia pada responden penelitian tersebut. Kebiasaan membaca dengan jarak kurang dari $30 \mathrm{~cm}$ akan meningkatkan keparahan dari miopia pada responden. Kebiasaan membaca pada jarak dekat (kurang dari $30 \mathrm{~cm}$ ) terjadi ketika seseorang harus fokus untuk melihat objek benda secara rinci. Kebiasaan ini akan menyebabkan tonus otot siliaris menjadi tinggi sehingga lensa menjadi cembung, akibatnya bayangan objek jatuh di depan retina dan menimbulkan miopia. Kebiasaan melihat dekat yang lama menyebabkan miopia melalui terbentuknya bayangan buram di retina (retina blur) yang terjadi selama fokus dekat. Bayangan buram di retina ini memulai proses biokimia pada retina untuk menstimulasi perubahan biokimia dan struktural pada sklera dan 
koroid yang menyebabkan elongasi aksial. Bila kebiasaan ini dilakukan terus-menerus maka akan menyebabkan kelelahan pada mata dan derajat myopia akan semakin berat. ${ }^{9,16}$ Untuk mengatasi masalah penurunan tajam penglihatan yang disebabkan oleh kebiasaan membaca dalam jarak yang terlalu dekat, maka perlu membiasakan membaca buku dengan jarak yang ideal yaitu lebih dari atau sama dengan $30 \mathrm{~cm}$ dan menggunakan waktu yang tidak terlalu lama.

Faktor lain yang mempengaruhi visus pada penelitian ini adalah ada tidaknya jenis sayuran kesukaan responden. Responden sebanyak 93 orang (83\%) memiliki jenis sayuran kesukaan, sebanyak 74 orang $(79,5 \%)$ mengalami penurunan visus oculi dextra, dan 76 orang $(81,7 \%)$ mengalami penurunan visus oculi sinistra. Responden yang tidak memiliki jenis sayuran kesukaan ada sebanyak 19 orang (17\%), terdapat 11 orang $(57,9 \%)$ yang mengalami penurunan visus oculi dextra, dan 10 orang $(52,6 \%)$ mengalami penurunan visus oculi sinistra.

Berdasarkan Riskesdas $2018^{17}$ ditemukan bahwa di Indonesia pada kelompok usia 10 tahun ke atas kurang konsumsi buah dan sayur sangat tinggi yaitu 95,5\% dari kebutuhan perhari dan di Sumatera Utara pada kelompok usia 10 tahun ke atas kurang konsumsi sayur dan buah berada di atas angka untuk seluruh Indonesia tersebut. Pada penelitian yang dilakukan oleh Muna ${ }^{18}$ diperoleh hasil bahwa faktor yang berhubungan dengan konsumsi buah dan sayur pada remaja adalah jenis kelamin, pengetahuan gizi, keterampilan dalam menyiapkan buah dan sayur, ketersediaan buah dan sayur di rumah, dukungan orangtua, dan dukungan teman sebaya. NeumarkSztainer et al. dalam penelitian ini mengemukakan bahwa kesukaan atau preferensi buah dan sayur memiliki hubungan secara langsung terhadap konsumsi buah dan sayur pada remaja. Jenis sayuran tertentu memiliki kandungan vitamin yang baik untuk kesehatan mata. Kurang konsumsi buah 
dan sayur juga bisa berdampak bagi kesehatan salah satunya yaitu menimbulkan gangguan penglihatan. ${ }^{18}$

Pada penelitian ini kebiasaan posisi membaca, rerata screentime, dan kebiasaan makan sayur tidak mempengaruhi visus responden. Hasil penelitian ini sesuai dengan penelitian Porotu'o $^{2}$ yang menunjukkan tidak adanya hubungan antara kebiasaan posisi membaca dengan penurunan visus $(\mathrm{p}=0,114)$, namun menunjukkan hasil yang berbeda karena menunjukkan bahwa rerata screentime akan mempengaruhi visus dengan nilai $\mathrm{p}=0,025$. Pada penelitian yang dilakukan Bawelle ${ }^{19}$ dan Panambuhan $^{10}$ menunjukkan bahwa tidak terdapat hubungan antara intensitas penggunaan gadget dengan ketajaman penglihatan. Berdasarkan penelitian Muna $^{18}$ kebiasaan makan sayur dipengaruhi oleh kemampuan untuk mempersiapkan buah dan sayur (misalnya: membersihkan, mencuci mencuci dengan benar, mengupas, memotong, dan mengiris). Memiliki keterampilan untuk menyiapkan makanan sehat di kalangan remaja akan mendorong peningkatan kualitas diet sehat termasuk kebiasaan makan sayur tersebut.

Dari hasil analisis regresi pada tabel 4 dapat diamati bahwa variabel yang mempengaruhi visus oculi dextra pada penelitian ini adalah kebiasaan jarak baca dengan nilai $\mathrm{p}=0,020$ dan OR sebesar 0,159. Sedangkan yang mempengaruhi visus oculi sinistra adalah kebiasaan jarak baca dan jenis sayuran kesukaan dengan masingmasing nilai $\mathrm{p}=0,034$ dan OR 0,364 serta $\mathrm{p}=0,010$ dan OR 0,244. Berdasarkan penelitian ini kebiasaan jarak baca kurang dari $30 \mathrm{~cm}$ mempunyai peluang meningkatkan kejadian penurunan visus oculi dextra sebanyak 0,159 kali dibandingkan responden yang memiliki kebiasaan jarak baca lebih dari atau sama dengan $30 \mathrm{~cm}$. Di sisi lain, kebiasaan jarak baca juga yang paling memiliki peluang yang lebih besar sebesar 0,364 kali untuk mempengaruhi visus oculi sinistra pada penelitian ini. 


\section{KESIMPULAN}

Dari hasil penelitian ini dapat disimpulkan bahwa mayoritas mahasiswa Fakultas Kedokteran Universitas HKBP Nommensen mengalami penurunan visus, terbanyak pada kategori penurunan ringan, dan ditemukan 2 responden yang termasuk kategori near blind. Faktor-faktor yang mempengaruhi visus pada responden secara statistik adalah kebiasaan jarak membaca (nilai $\mathrm{p}=0,015$ untuk oculi dextra dan $\mathrm{p}=0,028$ untuk oculi sinistra) dan jenis sayuran kesukaan (nilai $\mathrm{p}=0,044$ untuk oculi dextra dan $\mathrm{p}=0,006$ untuk oculi sinistra). Faktorfaktor seperti kebiasaan posisi membaca, rerata screentime, dan kebiasaaan makan sayur secara statistik tidak mempengaruhi visus pada penelitian ini karena nilai $p>0,05$.

\section{UCAPAN TERIMA KASIH}

Ucapan terima kasih kepada Dekan Fakultas Kedokteran Universitas HKBP Nommensen yang telah mengizinkan untuk dilaksanakannya penelitian ini. Ucapan terima kasih juga peneliti haturkan kepada Lembaga Penelitian dan Pengabdian Masyarakat Universitas HKBP Nommensen yang telah mendukung dana untuk terlaksananya penelitian ini.

\section{DAFTAR PUSTAKA}

1. Infodatin. Situasi Gangguan Penglihatan dan Kebutaan. 2014.

2. Porotu LI, Joseph WBS, Sondakh RC. Faktor-Faktor yang Berhubungan dengan Ketajaman Penglihatan pada Pelajar Sekolah Dasar Katolik Santa Theresia 02 Kota Manado. 2014; Available from: https://ejournal.unsrat.ac.id

3. Rukmini, Anggraini ED. Kebiasaan Membaca dan Ketajaman Penglihatan pada Siswa Kelas IV SDN Gubeng I Surabaya. Adi Husada Nurs J. 2017;3(2):7680.

4. Wardany Y, Arfiza NH, Arfianti. Pengaruh Kelainan Refraksi Terhadap Prestasi Belajar Murid Sekolah Dasar X Pekanbaru. J Kesehat Melayu. 2018;1(2):81-7. 
E-ISSN: 2614-5219

5. World Health Organization. Global Data on Visual Impairments 2010 [Internet]. Global Data on Visual Impairment 2010. 2010. Available from: http://www.who.int/blindness/GL

OBALDATAFINALforweb.pdf

6. World Health Organization. Global Initiative for the Elimination of Avoidable Blindness : action plan 2006-2011. World Health Organization; 2007.

7. Badan Penelitian dan Pengembangan Kesehatan Kementerian Kesehatan RI. Riset Kesehatan Dasar 2013. 2013.

8. Pan American Health Organization World Health Organization. Strategic Framework for Vision 2020: The Right to Sight. 2010.

9. Rozi AF, Rosalina, Novitasari D. Hubungan Kebiasaan Membaca Dengan Penurunan Ketajaman Penglihatan Anak Sekolah di SD Santo Antonius 02 Banyumanik Semarang. J Gizi dan Kesehat. 2015;7(16):174-81.

10. Panambuhan J, Rumampuk J,
Moningka MEW. Hubungan Penggunaan Smartphone dengan Ketajaman Penglihatan Pada Mahasiswa Laki-laki Fakultas Kedokteran Universitas Sam Ratulangi Angkatan 2015. J Med dan Rehabil. 2019;1(3):1-6.

11. Oktavani Y, Fadilah TF. Hubungan Antara Intensitas Penggunaan Game Online Dengan Visus pada Siswa di SMA. J Biomedika dan Kesehat. 2018;1(3):198-202.

12. Angriyanto KK. Hubungan Lama Membaca dan Menggunakan Komputer dengan Ametropia pada Mahasiswa Kedokteran Universitas Hang Tuah Semester VII Tahun Ajaran 2016-2017. Hang Tuah Med J. 2017;15(1):3240.

13. Adile A V, Tongku Y, Rares LM. Kelainan Refraksi pada Pelajar SMA Negeri 7 Manado. J e-Clinic. 2016;4(1):2-5.

14. Sofiani A, Santik YDP. Faktorfaktor Yang Mempengaruhi Derajat Miopia Pada Remaja 
(Studi di SMA Negeri 2 Temanggung Kabupaten Temanggung). Unnes J Public Heal. 2016;5(2):176-85.

15. Karim K, Taufiq I. Tingkat Penerangan dan Jarak Membaca Meningkatkan Kejadian Rabun Jauh ( Miopia ) pada Remaja. J Kesehat Metro Sai Wawai. 2017;10(2):103-8.

16. Saminan. Efek Bekerja Dalam Jarak Dekat Terhadap Kejadian Miopia. J Kedokt Syah Kuala. 2013;13(3):187-91.

17. Badan Penelitian dan Pengembangan Kesehatan Kementerian Kesehatan RI. Riset
Kesehatan Dasar 2018. 2018.

18. Muna NI, Mardiana. Faktor-Faktor yang Berhubungan Dengan Konsumsi Buah dan Sayur Pada Remaja. Sport Nutr J. 2019;1(1):111.

19. Bawelle CFN, Lintong F, Rumampuk J. Hubungan Penggunaan Smartphone dengan Fungsi Penglihatan pada Mahasiswa Fakultas Kedokteran Universitas Sam Ratulangi Manado Angkatan 2016. J eBiomedik. 2016;4(2):0-5. 